\title{
Post-IPO Operating Performance and Earnings Management
}

\author{
Nurwati A. Ahmad-Zaluki \\ Banking and Finance Building, College of Business \\ Universiti Utara Malaysia, 06010 Sintok \\ Kedah, Malaysia \\ Tel: 60-4-928-6451Ｅ-mail: nurwati@uum.edu.my
}

\begin{abstract}
The present study investigates the operating performance and the existence of earnings management for a sample of 254 Malaysian IPO companies over the period 1990-2000. Using accrual-based measure of operating performance, this study finds strong evidence of declining performance in the IPO year and up to three years following IPOs relative to the pre-IPO period. This finding is consistent with the results of prior studies documenting the long run underperformance of IPO companies. The results also confirm that the decline in post-IPO operating performance is due to the existence of earnings manipulation by the IPO manager at the time of going public.
\end{abstract}

Keywords: Initial public offerings, Operating performance, Earnings management

\section{Introduction}

Existing international studies of initial public offering (IPO) companies find that operating performance had declined in the post-IPO period (Jain and Kini, 1994; Mikkelson et al, 1997; Kim et al., 2004). The majority of prior studies are based on the accrual measure of accounting profits which are potentially subject to accounting manipulation by managers, for example through working capital adjustments (Teoh et al., 1998).

The most recent study of operating performance of Malaysian IPO companies was undertaken by Ahmad and Lim (2005) using a sample of 162 IPO companies during the period 1996 to 2000. Using the accrual-based operating performance measure, they found that there was a significant decline in the operating performance after the companies went public. They also found that only company size and pre-IPO profitability have significant influences on the post-IPO operating performance. Due to the fact that the Malaysian economy suffered an economic crisis in 1997 and 1998, with most companies suffering a decline in profitability (Note 1), the present study addresses the earnings management issue and re-examines the robustness of existing Malaysian evidence by using a larger sample (254 companies) and a longer time period (1990-2000).

This paper makes several contributions to the IPO and earnings management literatures. First, it investigates long run operating performance in a developing market whereas most prior research had focused on developed markets. Second, it extends prior operating performance literature by investigating the existence of earnings management at the time of the IPO. This will enable the assessment as to whether the post-IPO performance is potentially related to the reversal of pre-IPO accruals. Third, in addition to the post-IPO vs pre-IPO comparison made in prior studies to discover whether there is a change in operating performance following IPOs, the timing of changes in performance is also identified by comparing year-to-year performance. Finally, the sample is large and incorporates both private IPOs and privatisation IPOs, so it is more likely to be representative of the population of IPOs in the Malaysian market. (Note 2) In addition, a longer time period for the sample is used, therefore the results are not time period or crisis event specific.

The results provide evidence of deterioration in operating performance of IPO companies relative to matching companies following IPOs. Further investigation shows that earnings management exists at the time of IPOs. It suggests that erosion in operating performance is due to the result of the reversal of pre-IPO accruals that have been used by IPO managers to overstate pre-IPO earnings.

The remainder of this paper proceeds as follows. Section 2 provides a brief review of the literature concerning IPO operating performance and earnings management. Section 3 describes the sample selection and data. Section 4 outlines the research method. Section 5 reports the results of the empirical study. Finally, Section 6 summarises the results of the study.

\section{Literature review}


Among the relatively few studies that have focused on the accounting-based operating performance of IPOs, among others Jain and Kini (1994), Cai and Wei (1997), Mikkelson et al., (1997), Pagano et al., (1998), Kutsuna et al., (2002), Chan et al., (2003), Balatbat et al., (2004), Ahmad and Lim (2005) and Wang (2005). In general, most of these studies find poor operating performance in the post-IPO period.

The first study that examines the operating performance of IPO companies is undertaken by Jain and Kini (1994). They analyse the change in operating performance of 682 IPO companies in the US for the period 1976 to 1988 . They find a significant decline in both operating performance measures for a period of three to five years subsequent to the IPO relative to the one-year pre-IPO level performance, both before and after industry adjustment. They argue that the declining operating performance in the post-IPO period cannot be attributed to a decline in business activity such as lack of growth in sales or cutbacks in post-IPO capital expenditure. This is because they also find that their sample of IPO companies displayed strong growth in sales and capital expenditure following the IPOs. Similar results are also found by Chan et al. (2003) for Chinese IPO companies.

Teoh et al. (1998), while mainly focusing on earnings management and long run share price performance in the US, also provide evidence on the time-series distribution of accounting performance. They find that the median return on assets is significantly positive in year 0 but then declines, to be significantly negative, by year four.

The observed decline in the operating performance of IPO companies in general may not be too surprising. As pointed out by Jain and Kini (1994), managers may time their issues to follow periods of extraordinarily good performance. Investors may be overly optimistic about their companies' future performance based on the performance observed at the time of the IPO. Managers take advantage of this overvaluation by issuing equity when their equity is 'overvalued', thereby reducing their overall cost of equity. As a result of the 'overoptimism' hypothesis, Jain and Kini (1994) argue that IPOs are followed by significant declines in operating performance.

The earnings management hypothesis also suggests a potential explanation for poor post-IPO performance. According to this hypothesis, investors may overvalue new issues because of misinterpreted high earnings reported at the time of offerings, and that they fail to realise that the earnings management symbolises a transitory increase in earnings (Teoh et al., 1998). Therefore, investors are likely to be disappointed by the declining post-IPO operating performance and adjust their valuation downwards, which in turn causes the poor stock market performance. Existing literature in the US and the Netherlands (e.g., Teoh et al., 1998; Roosenboom et al., 2003) provides evidence in support of this hypothesis.

Empirical studies that focus on the relationship between earnings management and the performance of IPO companies began to appear in the late 1990s (e.g., Teoh et al., 1998; DuCharme et al., 2001, 2004; Roosenboom et al., 2003; Abdul Rahman and Wan Abdullah, 2005). In Malaysia, a paper by Abdul Rahman and Wan Abdullah (2005) is the only study that investigates earnings management by companies involved in IPOs. It finds evidence to support the existence of earnings management prior to the IPO, but no significant relationship between earnings management and post-IPO long run stock market performance for a sample period up to the year 1998. The present study builds on the study of Ahmad and Lim (2005) and Abdul Rahman and Wan Abdullah (2005) by investigating whether the operating performance of Malaysian IPO companies deteriorates in the post-IPO period, and if so, is the deterioration due to earnings management at the time of going public?

\section{Sample selection and data}

\subsection{Data sources}

Data were collected from various sources. (Note 3) Pre-IPO data were hand-collected from the offering prospectuses. The data were then cross-checked with the first published annual reports of the newly-listed companies which show comparative figures for the pre-IPO year and IPO year (immediately before and after listing). Post-IPO data were collected from different sources including Datastream, the Pacific-Basin Capital Markets (PACAP) database, the annual reports of the companies obtained from the Bursa Malaysia website at www.klse.com.my and the Public Information Centre of Bursa Malaysia.

\subsection{Sample selection}

\subsubsection{Selecting IPO companies}

There were 543 new companies listed on the KLSE during the period 1990 to 2000 . This period is selected to encompass recent IPOs and to have sufficient data on post-IPO operating performance.

For an IPO company to be included in the sample, the company had to be included in the Datastream database. Financial companies, companies that were listed via an 'introduction', companies that made a combination offering and companies that change their fiscal year end were all excluded from the sample. (Note 4) The final sample consists of 254 IPO companies after considering the availability of the first and subsequent published public annual reports, and an unchanged financial year end. (Note 5) The final sample comprised 508 companies, 254 IPO companies and their 254 
matching companies. Although just half of the potential numbers of Malaysian IPO companies remain, the large sample size suggests that it is likely to be representative. Prior study investigating the operating performance of Malaysian IPO companies used a sample of just 24 privatisation IPO companies (Sun and Tong, 2002). This study comprises 239 private IPOs and 15 privatisation IPO companies.

\subsubsection{Selecting matching companies}

Three criteria were used in the selection of matching companies, namely industry (to control for the industry sector), pre-operating performance (to control for a continuation of company specific performance before the IPOs) and total assets (to control for size effects). Barber and Lyon (1996) argue that the use of a matching company as a benchmark yields test statistics that are well specified. As argued by Perry and William (1994), companies that are in the same industry, have the same pre-IPO performance and are of similar sizes are assumed to have similar economic and competitive factors and to have comparable operating, investing, and financing opportunity sets.

The sample of IPO companies was individually matched according to the above three criteria. The matching process starts with a group of potential matching companies that had not been involved in an IPO in the last 3 years, in line with prior studies examining operating performance (e.g., Jain and Kini, 1994; and Loughran and Ritter, 1997). Companies are matched first by industry, then by pre-IPO performance and then by total assets. The present study does not employ the median industry performance benchmark because the small number of companies in certain Malaysian industries may introduce bias into the industry median computation. The pre-IPO performance matching was based on operating profit before tax divided by total sales. From this initial screen, the matched company is required to have pre-IPO operating performance within the range of $90 \%$ to $110 \%$ of sample IPO companies; and beginning total assets within $70 \%$ to $130 \%$ of sample IPO company total assets in year -1 . The same pre-operating performance and size filters were used by Barber and Lyon (1996). If a matched company cannot be found based on all three measures, the size criterion was relaxed and matching was based on industry and pre-IPO performance. Failure to match led to relaxation of the pre-IPO performance criterion, and matching was based solely on industry. In cases where insufficient potential matching industries were available, IPO companies were matched in terms of pre-IPO performance and total assets, regardless of industry. Finally, a small number of companies were matched on the basis of pre-IPO performance regardless of industry and total assets.

Of the 254 companies in the sample, 36 were matched on the basis of industry, pre-IPO performance, and total assets, 138 companies were matched on the basis of industry and pre-IPO performance, while 69 companies were matched on the basis of industry alone. Of the remaining 11 companies, 4 were matched on the basis of pre-IPO performance and total assets, while 7 were matched on the basis of pre-IPO performance regardless of industry. The present study was unable to match all companies using all three measures due to the fact that there are only a small number of Malaysian listed companies in certain industries.

\section{Methods}

\subsection{Measure of operating performance}

Various measures of operating performance are used to check the robustness of the results, using the accrual-based accounting profit approach: operating income on operating assets (OI/OA) and operating income on sales (OI/Sales). The operating income variables are all measured before taxes to avoid the effect of tax rate changes imposed by the Malaysian government during the period of analysis. (Note 6)

The choice of the denominator is contentious. Barber and Lyon (1996) suggest that total assets reflect both operating and non-operating assets, so may understate the true productivity of operating assets. The market value of assets is not used because market value data for IPO companies are not available prior to going public. Companies that have recently issued securities can experience a large increase in the book value of assets, but no immediate increase in operating profit or cash flows. As noted by Mikkelson et al. (1997), accounting profitability scaled by assets might give a downward bias after IPOs. To reduce such bias, this study also deflates the operating performance by total sales since these are unaffected by changes in the assets base (Barber and Lyon, 1996).

This study also examines the changes (Note 7) in accounting performance from the year immediately prior to the IPO (year -1 to 0 , year -1 to +1 , year -1 to +2 , year -1 to +3 ). To identify when changes (if any) took place, the year-to-year change from the previous year (year -1 to 0 , year 0 to +1 , year +1 to +2 , year +2 to +3 is also tested. Year -1 is the fiscal year prior to the IPO year, year 0 is the fiscal year of the IPO, year +1 is the fiscal year after the IPO, and so forth. The matched company-adjusted change for the IPO is the difference between the change in the operating performance for the IPO and its matched company. Again, the median (mean) change in matched company-adjusted performance is measured for year +1 , year +2 and year +3 relative to year -1 or each previous year. To test whether the medians were significantly different from zero, the Wilcoxon signed-ranks test and the $t$-test for mean values were used. The binomial proportionality test statistic was employed to test whether the percentage ( $p$ ) of the IPO companies outperforming their matched companies is different from what would be expected by chance (i.e. 50\%). 


\subsection{Measure of earnings management}

The present study also predicts that managers are most likely to positively manipulate earnings at the time of IPOs in order to increase their offering proceeds and maintain a high market price after IPOs. Following Teoh et al, (1998), among others, earnings management is measured using discretionary accruals. As argued by DuCharme et al. (2001), 'accruals not only reflect the choice of accounting methods but also the effect of recognition timing for revenues and expenses, asset write-downs, and changes in accounting estimates' (p.376). Since managers have more discretion over short term than over long term accruals (Teoh et al., 1998), this paper employs discretionary current accruals (DCA) to proxy for earnings management, as also used by Roosenboom et al. (2003) and DuCharme et al. (2001, 2004).

Using the accruals model as suggested by Dechow et al. (1995), the expected current accruals for each of the IPO sample companies in a given year are estimated using an estimation portfolio of all level 3 industry peers available on the Datastream and PACAP databases using the following cross-sectional model:

$$
\frac{C A_{j, t}}{T A_{j, t-1}}=\alpha_{0}\left(\frac{1}{T A_{j, t-1}}\right)+\alpha_{1}\left(\frac{\Delta \text { Sales }_{j, t}}{T A_{j, t-1}}\right)+\varepsilon_{j, t} \quad j \in \text { estimation portfolio }
$$

where CA is current accrual; $\mathrm{j}$ is companies which are in the same level 3 Datastream industry subsector but excludes the issuer and companies involved in an IPO in the previous three years; $\Delta$ Sales $_{j, t}$ is change in sales for company $\mathrm{j}$ in the industry estimation portfolio in year $\mathrm{t} ; T A_{j, t-1}$ is lagged total assets for company $\mathrm{j}$ in the industry estimation portfolio; $\mathcal{E}_{j, t}$ is regression disturbances, assumed cross-sectionally uncorrelated and normally distributed with zero means.

Similar to prior studies (e.g., Teoh et al., 1998; Roosenboom et al., 2003; DuCharme et al., 2004) all the variables are scaled by lagged total assets to reduce heteroscedasticity and to control for differences in company size. The change in sales is included to control for changes in nondiscretionary accruals caused by the change of economic conditions. A cross-sectional regression is performed separately in each fiscal year for each industry portfolio to estimate the coefficients $\alpha_{0}$ and $\alpha_{1}$, to control for changes in nondiscretionary accruals and to allow the nondiscretionary accruals to vary from period to period for different industries. Thus, the effect of changes in industry-wide economic circumstances in each specific year on current accruals is controlled. In addition, the coefficients $\alpha_{0}$ and $\alpha_{1}$ are allowed to change across years to allow for possible structural changes, such as management changes (DeFond and Jiambalvo, 1994).

An estimation portfolio is assigned for each of the IPO companies in the sample in order to estimate the coefficients $\alpha_{0}$ and $\alpha_{1}$. The present study restricts the analysis to estimating industry portfolios that consist of 10 companies or more in the same level 3 Datastream industrial classification of the IPO companies in the same fiscal year. IPO companies and companies that made an IPO in the previous three years are excluded from the industry portfolios. Due to the shortage of companies in certain industries, several similar industries are combined together. This results in six industry groups: (i) Basic; (ii) Consumer Goods (Cyclical and Non Cyclical); (iii) Services (Cyclical and Non Cyclical); (iv) General Industrials and Information Technology; (v) Resources and Utilities; and (vi) Real Estate Development.

After estimating the coefficients $\alpha_{0}$ and $\alpha_{1}$ from the current accruals model, the nondiscretionary accruals for each IPO company in each year are then predicted using the estimated coefficients $\alpha_{0}$ and $\alpha_{1}$ from each industry-year estimation portfolio. The nondiscretionary (expected) current accruals are the portion of current accruals that are not influenced by managerial discretion but are driven by the companies' sales growth.

Following Dechow et al. (1995) the change in trade receivables is subtracted from the change in sales to control for the possibility of credit sales manipulation by the issuer. The approach assumes that any change in the level of credit sales during the period reflects earnings management activity (Young, 1999). The nondiscretionary current accruals are then calculated as:

$$
N D C A_{i, t}=\hat{\alpha}_{0}\left(\frac{1}{T A_{i, t-1}}\right)+\hat{\alpha}_{1}\left(\frac{\Delta \text { Sales }_{i, t}-\Delta T R_{i, t}}{T A_{i, t-1}}\right)
$$

where $\alpha_{0}$ is estimated intercept; $\alpha_{1}$ is the slope coefficient for IPO company $i$ in year $t ; \Delta$ Sales $s_{i, t}$ is the change in sales for IPO company $i$ in year $t ; \Delta T R_{i, t}$ is the change in trade receivables for IPO company $i$ in year $t ; T A_{i, t-1}$ is lagged total assets for IPO company $i$ in year $t$.

Finally, the discretionary current accruals $(D C A)$, which are subject to managerial manipulation, are calculated as the difference between total current accruals and nondiscretionary current accruals. If non-zero $D C A$ is observed, it can be interpreted that earnings management exists during the year. Positive $D C A$ can be interpreted as income-increasing earnings management, and vice versa. The definition is:

DCA $A_{i, t}=\frac{C A_{i, t}}{T A_{i, t-1}}-N D C A_{i, t}$ 
where $C A_{i, t}$ is current accruals of IPO company $i$ in year $t ; T A_{i, t-1}$ is lagged total assets for IPO company $i$ in year $t$; and $N D C A_{i, t}$ is nondiscretionary current accruals for IPO company $i$ in year $t$.

\section{Results}

\subsection{Descriptive statistics}

Table 1 presents the descriptive statistics for 254 IPOs and 254 matched companies. The information is pre-IPO, with market value measured on the flotation date. The median (mean) operating return on sales (OI/Sales) for the sample of IPO and matched companies is $13.9 \%(16.3 \%)$ and $13.6 \%(15.3 \%)$, respectively. These are expected to be similar since the IPO companies have been matched primarily on OI/Sales. While the difference between medians is not statistically significant, the difference between means OI/Sales is statistically significant at the $5 \%$ level. There is a wide variation in this operating margin; IPO companies range between $-24 \%$ and $63 \%$ and the matched companies between $-26 \%$ and $52 \%$. The skewness (and kurtosis) is typical for company size measures generally, but also suggest a larger positive tail with greater central clustering for IPO companies.

The absolute figures of operating profit before tax, total sales, total assets, equity capital and reserves, market value, and total debt show some differences between IPO and matched companies. There are significant differences in both median and mean values at the $1 \%$ level. For example, the median (mean) total sales for IPO companies is RM65 million (RM125 million) compared with RM137 million (RM784 million) for matched companies. The difference is partly a function of the procedure used in size matching, since IPO companies were usually matched with the nearest larger non-IPO company in terms of size, even though size range between $70 \%$ and $130 \%$ of IPO company was used. Similar observations occur for the other size measures. The highest market value of RM26,250 million for IPO companies is observed for Tenaga Nasional Berhad. Meanwhile, the lowest market value of RM24 million is observed for Carpet International Malaysia Berhad.

While the total debt of IPO companies is also smaller than for their matched companies, the gearing levels are significantly higher at the $1 \%(10 \%)$ level for medians (means). The median (mean) debt/equity ratio is $40 \%(64 \%)$ for IPO companies compared with $24 \%$ (49\%) for matched companies. This is not surprising given the desire to raise new equity finance expressed in the IPOs.

\subsection{Level of operating performance}

Prior to investigating the changes in the operating performance of Malaysian IPO companies, it is useful to consider the level of operating performance of IPO companies and their respective matched companies over time for the pre-IPO year, the IPO year, and the post-IPO years. The analysis of performance is conducted to identify any differences between IPO companies and matched companies throughout the years $-1,0,+1,+2$, and +3 . Similar to Jain and Kini (1994), Mikkelson et al. (1997), and Kim et al. (2004), this paper focuses on median performance due to the tendency of accounting ratios to contain outliers in the data. However, for completeness, the results based on means are also reported.

As can be seen from Table 2, both the median levels of operating performance measures (OI/OA and OI/Sales) of the IPO companies are higher than those of the matched companies in the year prior to the IPO and the IPO year. Both measures are significantly different at the $1 \%$ level except for the pre-IPO median level of OI/Sales. These results are confirmed by a significant percentage positive, with more than $50 \%$ observed in year -1 and 0 . While the median levels of OI/OA of the IPO companies continue to outperform the matched companies up to year +2 , the levels are not significantly different. The OI/Sales measure shows that the IPO companies underperform the matched companies subsequent to year 0. Both accrual-based measures show that IPO companies significantly underperformed the matched companies in the third year following the IPOs at the $1 \%$ level. (Note 8 )

\subsection{Change in operating performance}

Reported in Table 3 are the median and mean changes in operating performance for IPO companies and matched company-adjusted results. Panel A reports the results of the pre- and post-IPO changes, while Panel B provides the results of the year-to-year changes.

As can be seen in Panel A of Table 3, all of the median OI/OA values decline from their pre-IPO levels. All of them are significantly different from zero at the $1 \%$ level. The results are consistent with US studies by Jain and Kini (1994) who found a decline of $9.09 \%$ in return on assets three years after the IPO, and by Kim et al. (2004). The matched company-adjusted results control for economy-wide, industry-wide, pre-event performance and size and exhibit a decline throughout all performance windows from year 0 onwards. The median matched company-adjusted changes range from $-0.1 \%$ to $-8.1 \%$ and all except the first are statistically significant, indicating that IPO companies have a higher rate of decline than that of their matched companies. This shows that the decline in post-IPO OI/OA is not simply due to an industry-effect, mean reversion or size. The decline in OI/OA from year -1 suggests that the IPO companies may time their issues to occur after good performance. Interestingly, results for changes in the less 
downward-biased measures, OI/Sales, show that there is a slight improvement in performance in year 0 relative to year -1 for the IPO companies. However, this improvement is not statistically significant. Subsequent to the IPO, there is a significant decline in performance in OI/Sales for IPO companies.

The year-to-year changes in OI/OA reported in Panel B also show significant declines in performance, with the rate of decline slowing down somewhat over time. After controlling for companies matched by similar industry, pre-IPO performance and size, the changes in OI/OA still show significant declines except for the change from year -1 to 0 . Thus, it is clear that IPOs in Malaysia do show deterioration in accruals-based returns on operating assets for the three post-IPO years.(Note 9) Contrary to expectation, this study did not find a large decline in OI/OA in the year -1 to 0 , although this was observed in year 0 to +1 . The median OI/Sales for the IPO companies peaks in the IPO year and then declines following the IPO. Consistent with the OI/OA results, the highest decline occurs in the year immediately following the IPO (year 0 to +1 ).

In sum, the evidence suggests that the accrual-based operating performance of IPO companies is higher prior to the IPO but declines thereafter, subject to a slight improvement in operating margins in the IPO year (year -1 to 0 ). This suggests that Malaysian companies may time their IPOs to coincide with peak performance and/or may increase their assets more rapidly than sales. There is also evidence that IPO companies underperform their matched companies from the year following the IPO. Moreover, the evidence is consistent with previous empirical results (e.g., Jain and Kini, 1994, and Kim et al., 2004) which reported a deterioration in accrual-based operating performance following IPOs.

Overall, it is clear that both accrual performance measures show higher pre-IPO performance, consistent with Kim et al.'s (2004) study on the Thailand market. There is evidence of post-IPO underperformance relative to control matched companies, consistent with the Mikkelson et al.'s (1997) study on the US market and the findings of Cai and Wei (1997) based on the Japanese market. The deterioration in performance may be the result of the reversal of pre-event accruals that have been used by IPO managers to overstate pre-IPO earnings. Therefore, in the next section, an analysis of the potential earnings manipulation of IPO managers is provided.

\subsection{Earnings management}

Table 4 presents the evidence for the likelihood of earnings management, proxied by the discretionary current accruals (DCA), at the time of the IPOs (year 0) classified by year of listing. All values are expressed as a percentage of lagged total assets.

The present study relies on the medians for statistical inference since some skewness is indicated in the sample by a higher mean measure than median measure in year 0 . In addition, the test of normality based on the Kolmogorov-Smirnov statistic of $0.156(p$-value $=0.000)$ indicates that the data differs significantly from a normal distribution, thus violating one of the assumptions of parametric tests.

The median (mean) DCA is higher at the time of the IPOs (year 0), at 3.24\% (5.74\%) of lagged total assets. The results of the present study strongly support the likelihood of earnings management at the time of IPOs, indicated by a significant positive (at the $1 \%$ level) DCA. The level of earnings management at the time of IPO is slightly lower than the results observed by Teoh et al. (1998) and Roosenboom et al. (2003), who reported median values of 5.5\% and $3.9 \%$. Teoh et al. (1998) confine their study to conditions in US whereas Roosenboom et al. (2003) focus on the Netherlands. However, as reported by Roosenboom et al. (2003), other studies have observed similar levels of earnings management, ranging from $1.5 \%$ to more than $5 \%$ of lagged total assets. Overall, the evidence reported in Table 4 is consistent with Teoh et al. (1998) and Roosenboom et al. (1003) and suggests that the managers of Malaysian IPO companies opportunistically advance accruals in an attempt to improve earnings during the IPO year. Thus, the evidence provides a possible explanation for the observed decline in operating performance reported in the previous section.

\section{Summary}

This paper is the first detailed, large sample study of the long run operating performance and earnings management of Malaysian IPO companies, and covers the period 1990 to 2000. The main results of this study can be summarised as follows. First, comparison of pre- and post IPO accounting-based operating performance in terms of levels and changes provides some interesting findings. There is moderate evidence supporting the view that the average IPO company in Malaysia underperforms seasoned companies over the three year post-IPO period. However, there is strong evidence of declining performance in the IPO year and up to three years following the IPO. The year-to-year analysis reveals that the decline in performance is greatest in the year immediately following the IPO. This finding is consistent with the results of prior studies documenting the long run underperformance of IPOs. The results also confirm that the deterioration in the post-IPO operating performance is due to earnings management by IPO managers at the time of going public.

\section{References}


Abdul Rahman, R., \& Wan Abdullah, W.R. (2005). The new issue puzzle in Malaysia: performance and earnings management. National Accounting Research Journal, 3, pp. 91-110.

Ahmad, Z., \& Lim, S.M. (2005). Operating performance of initial public offerings in Malaysia. Capital Market Review, 13, pp. 21-32.

Balatbat, M.C.A., Taylor, S.L., \& Walter, T.S. (2004). Corporate governance, insider ownership and operating performance of Australian initial public offerings. Accounting and Finance, 44, pp. 299-328.

Barber, B. M., \& Lyon, J. D. (1996). Detecting abnormal operating performance: The empirical power and specification of test statistics. Journal of Financial Economics, 41, pp. 359-399.

Cai, J., \& Wei, K.C. J. (1997). The investment and operating performance of Japanese initial public offerings. Pacific-Basin Finance Journal, 5, pp. 389-417.

Chan, K., Wang, J., \& Wei, K.C. J. (2003), Underpricing and long-term performance of IPOs in China. Journal of Corporate Finance, 10, pp. 409-430.

Dechow, P.M., Sloan, R.G., \& Sweeney, A.P. (1995). Detecting earnings management. Accounting Review, 70, pp. 193-225.

DeFond, M.L., \& Jiambalvo, J. (1994). Debt covenant violation and manipulation of accruals. Journal of Accounting and Economics, 17, pp. 145-176.

DeGeorge, F., \& Zeckhauser, R. (1993). The reverse LBO decision and firm performance: theory and evidence. Journal of Finance, 48, pp. 1323-1348.

Jain, B.A., \& Kini, O. (1994). The post-issue operating performance of IPO firms. Journal of Finance, 49, pp. 1699-1726.

Kaplan, S.N. (1989). The effects of management buyouts on operating performance and value. Journal of Financial Economics, 24, pp. 217-254.

Kim, K.A., Kitsabunnarat, P., \& Nofsinger, J.R. (2004). Ownership and operating performance in an emerging market: evidence from Thai IPO firms. Journal of Corporate Finance, 10, pp. 355-381.

Kutsuna, K., Okamura, H., \& Cowling, M. (2002). Ownership structure pre- and post-IPOs and the operating performance of JASDAQ companies. Pacific-Basin Finance Journal, 10, pp. 163-181.

Loughran, T., \& Ritter, J.R. (1997). The operating performance of firms conducting seasoned equity offerings. Journal of Finance, 52, pp. 1823-1850.

Mikkelson, W.H., Partch, M.M., \& Shah, K. (1997). Ownership and operating performance of companies that go public. Journal of Financial Economics, 44, pp. 281-307.

Mohd Saleh, N., \& Ahmed, K. (2005). Earnings management of distressed firms during debt renegotiation. Accounting and Business Research, 35, pp. 69-86.

Pagano, M., Panetta, F., \& Zingales, L. (1998). Why do companies go public? An empirical analysis. Journal of Finance, 53, pp. 27-64.

Roosenboom, P., van der Goot, T., \& Mertens, G. (2003). Earnings management and initial public offerings: evidence from the Netherlands. International Journal of Accounting, 38, pp. 243-266.

Sun, Q., \& Tong, W.H.S. (2002). Malaysia privatization: a comprehensive study. Financial Management, 31, pp. 79-105.

Teoh, S.H., Welch, I., \& Wong, T.J. (1998). Earnings management and the long-run market performance of initial public offerings. Journal of Finance, 53, pp. 1935-1974.

Wang, C. (2005). Ownership and operating performance of Chinese IPOs. Journal of Banking and Finance, 29, pp. 1835-1856.

Young, S. (1999). Systematic measurement error in the estimation of discretionary accruals: an evaluation of alternative modeling procedures. Journal of Business Finance and Accounting, 26, pp. 833-862.

Notes

Note 1. Overall, the total earnings after tax of listed non-financial companies declined by RM3 billion and RM14 billion in 1997 and 1998, respectively (Mohd Saleh and Ahmed, 2005).

Note 2. Sun and Tong (2002) investigate the operating performance of 24 privatisation IPOs (PIPOs) in Malaysia for the period 1983-1997. However, their small sample is not representative of the overall population of IPOs which consist of both private and previously state-owned companies. In addition, they did not investigate the existence of earnings 
management. The term PIPO is used to refer to situations when a public listing is used to transform part or all of the government's ownership in state-owned enterprises into private ownership.

Note 3. Five years of data on each proxy variable had to be available for each company and matched company to examine the pre- and post IPO changes, and year-to-year changes in performance. The periods examined are the pre-IPO year, the IPO year, and each of the three post-IPO years.

Note 4. Companies that are listed under Finance, Trust and Closed-End Funds sectors are excluded. The Properties sector was included in the sample because it is not classified in the financial sector by the KLSE. The companies that are listed via 'introduction' are excluded because they are not strictly IPOs. The company that issue debt together with equity are excluded to avoid any confounding effects of debt issue.

Note 5. There is no accounting data for a particular year when a company changes its fiscal year end. In addition, the data were reported inconsistently due to the fact that the financial statements were presented for periods with varying time-spans, which limits the comparability of the accounting measures. However, if this occurred to the matched company, it was removed and the process of finding another matching company was repeated.

Note 6. The corporate tax rate was 35\%, 34\%, 32\%, 30\%, and 28\% in the years 1989-1992, 1993, 1994, 1995-1997, and 1998-2004 respectively (The Malaysian Inland Revenue Board).

Note 7. A similar method to measure change has been used by Kaplan (1989) and Degeorge and Zeckhauser (1993) on leverage buyout (LBOs), and by Jain and Kini (1994) on IPOs. The absolute change rather than the percentage change is used to avoid the negative denominator problem, whereby companies with poor performance (negative value) need to be removed from the calculation of percentage change.

Note 8. For comparison with prior studies, the unreported results on the operating return on total assets are qualitatively similar with the results based on the operating return on operating assets.

Note 9. To test the robustness of the results, operating return on total assets was also measured and the unreported results show similar patterns.

Table 1. Descriptive statistics for 254 IPO companies and 254 matched companies

\begin{tabular}{|c|c|c|c|c|c|c|}
\hline & & Mean & Median & Std Dev & Min & Max \\
\hline \multirow{2}{*}{ OI/Sales (\%) } & IPO & $16.32^{\mathrm{b}}$ & 13.93 & 10.20 & -24.32 & 62.90 \\
\hline & Matched & 15.33 & 13.56 & 10.05 & -26.32 & 52.08 \\
\hline \multirow{2}{*}{$\begin{array}{l}\text { Operating profit before } \\
\operatorname{tax}(\text { million RM) }\end{array}$} & IPO & $18^{\mathrm{a}}$ & $9^{a}$ & 56 & -21 & 702 \\
\hline & Matched & 113 & 20 & 274 & -19 & 2376 \\
\hline \multirow{2}{*}{$\begin{array}{l}\text { Total sales } \\
\text { (million RM) }\end{array}$} & IPO & $125^{\mathrm{a}}$ & $65^{\mathrm{a}}$ & 295 & 9 & 3702 \\
\hline & Matched & 784 & 137 & 1733 & 7 & 10780 \\
\hline \multirow{2}{*}{$\begin{array}{l}\text { Total assets } \\
\text { (million RM) }\end{array}$} & IPO & $219^{\mathrm{a}}$ & $70^{\mathrm{a}}$ & 1086 & 2 & 14855 \\
\hline & Matched & 1342 & 275 & 3676 & 30 & 26526 \\
\hline \multirow{2}{*}{$\begin{array}{lr}\text { Equity } & \text { capital and } \\
\text { reserves } & \text { (million } \\
\text { RM) } & \end{array}$} & IPO & $91^{\mathrm{a}}$ & $31^{\mathrm{a}}$ & 431 & -11 & 6071 \\
\hline & Matched & 616 & 155 & 1486 & -27 & 14459 \\
\hline \multirow{2}{*}{$\begin{array}{l}\text { MV at flotation } \\
\text { (million RM) }\end{array}$} & IPO & $545^{\mathrm{a}}$ & $180^{\mathrm{a}}$ & 2051 & 25 & 36166 \\
\hline & Matched & 1538 & 389 & 3699 & 18 & 28134 \\
\hline \multirow{2}{*}{$\begin{array}{l}\text { Total debt } \\
\text { (million RM) }\end{array}$} & IPO & $71^{\mathrm{a}}$ & $11^{\mathrm{a}}$ & 455 & 0 & 5670 \\
\hline & Matched & 377 & 40 & 1658 & 0 & 15023 \\
\hline \multirow{2}{*}{ Total debt/equity (\%) } & IPO & $64^{\mathrm{c}}$ & $40^{\mathrm{a}}$ & 139 & -11 & 1938 \\
\hline & Matched & 49 & 24 & 77 & -334 & 538 \\
\hline
\end{tabular}

This table presents the descriptive statistics for 254 IPOs and 254 matched companies. The information is based on pre-IPO date, except for market value data that is measured on the flotation date.

${ }^{a, b}$ IPO and matched company values significantly different at the 0.01 and 0.05 level respectively, using a two-tailed test. 
Table 2. The median and mean levels of operating performance

\begin{tabular}{|c|c|c|c|c|c|c|c|c|}
\hline & \multicolumn{3}{|c|}{$\begin{array}{l}\text { Median level (\%) } \\
\qquad \mathrm{n}=254\end{array}$} & \multicolumn{3}{|c|}{$\begin{array}{l}\text { Mean level (\%) } \\
\qquad \mathrm{n}=254\end{array}$} & \multicolumn{2}{|c|}{$\begin{array}{c}\text { IPO - Non-IPO } \\
n=254\end{array}$} \\
\hline $\begin{array}{l}\text { Fiscal Year } \\
\text { Relative to } \\
\text { IPO }\end{array}$ & IPO & $\begin{array}{c}\text { Non-IP } \\
\text { O }\end{array}$ & Z-stat & IPO & $\begin{array}{c}\text { Non-IP } \\
\mathrm{O}\end{array}$ & t-stat & $\%$ tve & Z-stat \\
\hline $\begin{array}{l}\text { Panel A: } \\
\text { OI/OA }\end{array}$ & & & & & & & & \\
\hline-1 & 14.28 & 9.62 & $6.71^{\mathrm{a}}$ & 18.02 & 11.34 & $5.05^{\mathrm{a}}$ & 70.08 & $6.40^{\mathrm{a}}$ \\
\hline 0 & 12.91 & 7.50 & $7.39^{\mathrm{a}}$ & 15.08 & 8.52 & $4.99^{\mathrm{a}}$ & 72.83 & $7.28^{\mathrm{a}}$ \\
\hline 1 & 8.22 & 6.64 & 1.52 & 9.50 & 6.59 & $2.30^{b}$ & 53.15 & 1.00 \\
\hline 2 & 6.89 & 6.27 & 0.13 & 6.94 & 5.72 & 0.90 & 49.61 & -0.13 \\
\hline 3 & 4.89 & 6.04 & $-3.40^{\mathrm{a}}$ & 1.47 & 6.88 & $-2.71^{a}$ & 40.16 & $-3.14^{\mathrm{a}}$ \\
\hline $\begin{array}{l}\text { Panel B: } \\
\text { OI/Sales }\end{array}$ & & & & & & & & \\
\hline-1 & 13.93 & 13.56 & 0.82 & 16.32 & 15.33 & $2.18^{b}$ & 50.39 & 0.13 \\
\hline 0 & 14.25 & 12.38 & $4.31^{\mathrm{a}}$ & 16.92 & 16.48 & 0.12 & 59.84 & $3.14^{\mathrm{a}}$ \\
\hline 1 & 9.75 & 10.28 & -0.64 & 11.59 & 9.00 & 0.80 & 45.67 & -1.38 \\
\hline 2 & 8.97 & 10.17 & -1.12 & 8.19 & 5.37 & 0.79 & 44.88 & -1.63 \\
\hline 3 & 5.94 & 9.89 & $-3.60^{\mathrm{a}}$ & 1.90 & 5.80 & -0.81 & 38.98 & $-3.51^{\mathrm{a}}$ \\
\hline
\end{tabular}

This table reports the median levels of operating performance measures (OI/OA and OI/Sales) of the IPO companies and matching companies in the year prior to the IPO (year -1) up to three years following IPOs. OI/OA is measured by operating profit before tax/(total assets-cash and equivalents), while OI/Sales is based on operating profit before $\operatorname{tax} /$ (total sales).

a, b, c denote significantly different from zero at the $0.01,0.05$, and 0.10 level respectively, using a two-tailed test. 
Table 3. The median and mean changes in operating performance

\begin{tabular}{|c|c|c|c|c|c|c|c|c|}
\hline & \multicolumn{2}{|c|}{$\begin{array}{l}\text { Median } \\
\text { Mean }\end{array}$} & \multicolumn{2}{|c|}{$\begin{array}{l}\text { Median } \\
\text { Mean }\end{array}$} & \multicolumn{2}{|c|}{$\begin{array}{l}\text { Median } \\
\text { Mean }\end{array}$} & \multicolumn{2}{|c|}{$\begin{array}{l}\text { Median } \\
\text { Mean }\end{array}$} \\
\hline $\begin{array}{l}\text { Pre-post-IPO changes } \\
(\%)\end{array}$ & \multicolumn{2}{|c|}{ Year -1 to 0} & \multicolumn{2}{|c|}{ Year -1 to +1} & \multicolumn{2}{|c|}{ Year -1 to +2} & \multicolumn{2}{|c|}{ Year -1 to +3} \\
\hline \multicolumn{9}{|l|}{$\mathrm{OI} / \mathrm{OA}$} \\
\hline IPO company & $-1.20^{\mathrm{a}}$ & $-2.94^{b}$ & $-6.06^{\mathrm{a}}$ & $-8.52^{\mathrm{a}}$ & $-7.50^{\mathrm{a}}$ & $-11.08^{\mathrm{a}}$ & $-10.24^{\mathrm{a}}$ & $-16.55^{\mathrm{a}}$ \\
\hline Matched -adjusted & -0.08 & -0.11 & $-4.36^{\mathrm{a}}$ & $-3.76^{b}$ & $-5.87^{\mathrm{a}}$ & $-5.45^{\mathrm{a}}$ & $-8.07^{\mathrm{a}}$ & $-12.09^{a}$ \\
\hline OI/Sales & & & 4 & & & & & \\
\hline IPO company & 0.29 & 0.60 & $-2.91^{\mathrm{a}}$ & $-4.73^{\mathrm{a}}$ & $-4.46^{\mathrm{a}}$ & $-8.13^{\mathrm{a}}$ & $-7.04^{\mathrm{a}}$ & $-14.42^{\mathrm{a}}$ \\
\hline Matched -adjusted & $1.80^{\mathrm{a}}$ & -0.55 & -1.54 & 1.60 & -2.09 & 1.83 & $-4.64^{\mathrm{a}}$ & -4.89 \\
\hline $\begin{array}{l}\text { Panel B: } \\
\text { Year-to-year changes } \\
(\%)\end{array}$ & \multicolumn{2}{|c|}{ Year -1 to 0} & \multicolumn{2}{|c|}{ Year 0 to +1} & \multicolumn{2}{|c|}{ Year +1 to +2} & \multicolumn{2}{|c|}{ Year +2 to +3} \\
\hline \multicolumn{9}{|l|}{ OI/OA } \\
\hline IPO company & $-1.20^{\mathrm{a}}$ & $-2.94^{\mathrm{b}}$ & $-4.21^{\mathrm{a}}$ & $-5.58^{\mathrm{a}}$ & $-1.42^{\mathrm{a}}$ & $-2.56^{\mathrm{a}}$ & $-1.97^{\mathrm{a}}$ & $-5.47^{\mathrm{a}}$ \\
\hline Matched -adjusted & -0.08 & -0.11 & $-3.44^{\mathrm{a}}$ & $-3.65^{b}$ & $-1.84^{\mathrm{a}}$ & -1.69 & $-1.81^{\mathrm{a}}$ & $-6.64^{\mathrm{a}}$ \\
\hline \multicolumn{9}{|l|}{ OI/Sales } \\
\hline IPO company & 0.29 & 0.60 & $-3.05^{\mathrm{a}}$ & $-5.33^{\mathrm{a}}$ & $-0.97^{\mathrm{a}}$ & $-3.40^{\mathrm{a}}$ & $-1.65^{\mathrm{a}}$ & $-6.29^{\mathrm{a}}$ \\
\hline Matched -adjusted & $1.80^{\mathrm{a}}$ & -0.55 & $-2.90^{\mathrm{a}}$ & 2.15 & -1.12 & 0.23 & $-2.16^{\mathrm{a}}$ & -6.72 \\
\hline
\end{tabular}

This table reports the median and mean changes in operating performance for IPO companies and after adjusting the performance of the matching companies, referred to as matched -adjusted. Year -1 is the year prior to the IPO, year 0 is the IPO year and so forth. OI/OA is measured by operating profit before tax/(total assets-cash and equivalents), while $\mathrm{OI} / \mathrm{Sales}$ is based on operating profit before tax/(total sales).

${ }^{\mathrm{a}, \mathrm{b}, \mathrm{c}}$ denote significantly different from zero at the $0.01,0.05$, and 0.10 level respectively, using a two-tailed test. 